\title{
Artan Dozlarda Bakır Sülfat ve Azot Uygulamalarının Ekmeklik Buğdayda Verim ile Kök ve Kök Boğazı Çürüklüğü Hastalığına Etkileri
}

Effects of Copper Sulfateand Nitrogen Applications in The Increasing Doses On The Yield and Root and Root Crown Rot Disease of Bread Wheat

\section{Muhammet Nurullah AKDAĞ ${ }^{1 *}$ Mehmet ZENGİN ${ }^{2}$}

\begin{abstract}
$\ddot{\mathbf{O} z}$
$\mathrm{Bu}$ çalışma, artan dozlarda bakır sülfat (BS; $\mathrm{CuSO}_{4} \cdot 5 \mathrm{H}_{2} \mathrm{O} ; \% 35 \mathrm{Cu}$ ) ve azot uygulamalarının Quality çeşidi ekmeklik buğdayda verim ve verim unsurları ile kök ve kök boğazı çürüklüğü hastalığına (KKBÇH) etkilerini tespit etmek amaciyla 2016-2017 üretim sezonunda Konya'nın Sarayönü İlçesi'nin Değirmenli Mahallesi’nde 0 ada 307 parsel numaralı bir çiftçi tarlasında yağmurlama sulamalı koşullarda yapılmıştır. Çalışmada 3 blok ve her blokta 24 parsel olmak üzere toplam 72 parsel oluşturulmuştur. Bloklara 10,15 ve $20 \mathrm{~kg} \mathrm{~N} \mathrm{da}^{-1}$ dozları uygulanmıştır. Ayrıca her blokta kendi içinde 4 tekerrürlü olarak $0,0.5,1,2,4$ ve $6 \mathrm{~kg} \mathrm{BS} \mathrm{da}^{-1}$ dozları kullanılmıştır. Araştırma sonuçlarına göre, en yüksek buğday verimi $\left(405 \mathrm{~kg} \mathrm{da}^{-1}\right)$ ' $15 \mathrm{~kg} \mathrm{~N} \mathrm{da}^{-1}+4 \mathrm{~kg} \mathrm{BS} \mathrm{da}^{-1}$ ' uygulamasından alınmışıır. Ayrıca $10 \mathrm{~kg} \mathrm{~N} \mathrm{da}^{-1}$ bloğunda $2 \mathrm{~kg} \mathrm{BS} \mathrm{da}^{-1}$ dozu ve üzeri dozlarda, $15 \mathrm{~kg} \mathrm{~N} \mathrm{da}^{-1} \mathrm{ve} 20 \mathrm{~kg} \mathrm{~N} \mathrm{da}^{-1}$ bloklarında ise $4 \mathrm{~kg} \mathrm{BS} \mathrm{da}{ }^{-1}$ dozu ve üzerindeki dozlarda BS uygulanan parsellerde KKBÇH'nın oluşmadığı belirlenmiştir. Uygulanan $\mathrm{N}$ dozlarının buğdayda verim ve verim unsurlarına etkilerine bakıldığında, en yüksek verim ve verim unsurları değerleri $15 \mathrm{~kg} \mathrm{~N} \mathrm{da}^{-1}$ uygulamasından elde edilmiştir. Bu yüzden benzer koşullardaki buğday yetiştiriciliğinde $15 \mathrm{~kg} \mathrm{~N} \mathrm{da}^{-1} \mathrm{ve} 4 \mathrm{~kg} \mathrm{BS} \mathrm{da}^{-1}$ dozlarının kullanılması önerilebilir.
\end{abstract}

Anahtar Kelimeler: Azot, bakır sülfat, buğday, kök ve kök boğazı çürüklüğü

\begin{abstract}
This study was carried out to determine the effects of in the increasing dozes of copper sulfate (CS; $\mathrm{CuSO}_{4} .5 \mathrm{H}_{2} \mathrm{O}$; $35 \% \mathrm{Cu}$ ) and nitrogen applications on the yield and yield components, root and root crown disease of Quality variety bread wheat grown in a farmer field with spring irrigation in Değirmenli Town of Sarayönü District of Konya Province in 2016-2017 growing season. In the field experiment, the three block and 24 plots in each block, total 72 plots were formed. 100, 150 and $200 \mathrm{~kg} \mathrm{~N} \mathrm{ha}^{-1}$ dozes were applied into blocks. In addition, 0, 5, 10, 20, 40 and $60 \mathrm{~kg} \mathrm{CS} \mathrm{ha}^{-1}$ dozes were given into each block as four replications. According to the results, the highest wheat yield $\left(4.050 \mathrm{~kg} \mathrm{ha}^{-1}\right)$ was obtained from ' $150 \mathrm{~kg} \mathrm{~N} \mathrm{ha}^{-1}+40 \mathrm{~kg} \mathrm{CS} \mathrm{ha}^{-1}$ ' dozes. In addition, the root and root crown diseases were not seen in the $20 \mathrm{~kg} \mathrm{CS} \mathrm{ha}^{-1}$ doze and more high dozes in the $100 \mathrm{~kg} \mathrm{~N} \mathrm{ha}^{-1}$ block. The same diseases were not determined in the $40 \mathrm{~kg} \mathrm{CS} \mathrm{ha}^{-1}$ doze and more high dozes in the 150 and $200 \mathrm{~kg} \mathrm{~N}^{-1}$ blocks. $^{-1}$ When it was look at the effects of $\mathrm{N}$ dozes applied, the highest yield and yield components were obtained from $150 \mathrm{~kg} \mathrm{~N} \mathrm{ha}^{-1}$ doze (2. block). So, $150 \mathrm{~kg} \mathrm{~N} \mathrm{ha}^{-1}$ and $40 \mathrm{~kg} \mathrm{CS} \mathrm{ha}^{-1}$ dozes can be suggested in the wheat growing in the similar conditions.
\end{abstract}

Keywords: Nitrogen, copper sulfate, wheat, root and root crown.

\footnotetext{
1*Sorumlu Yazar/Corresponding Author: Muhammet Nurullah Akdağ, Sarayönü İlçe Tarım ve Orman Müdürlüğü, Konya. Türkiye E-mail: akdagnurullah@gmail.com, (D) OrcID: 0000-0002-9445-178X

${ }^{2}$ Mehmet Zengin, Selçuk Üniversitesi, Ziraat Fakültesi, Toprak Bilimi ve Bitki Besleme Bölümü, Konya. Türkiye. E-mail: x@ hotmail.com. (iD) OrcID: 0000-0001-9330-0253

Atıf/Citation: Akdağ, M., N., Zengin, M. 2020. Artan dozlarda bakır sülfat ve azot uygulamalarının ekmeklik buğdayda verim ile kök ve kök boğazı çürüklüğü hastalığına etkileri. Tekirdağ Ziraat Fakültesi Dergisi, 17(2), 149-161.
} 


\section{Extendend Summary}

This study was carried out to determine the effects of increasing dozes of copper sulphate $\left(\mathrm{CS} ; \mathrm{CuSO}_{4} .5 \mathrm{H}_{2} \mathrm{O}\right.$; $35 \% \mathrm{Cu}$ ) and nitrogen applications on the yield and yield components of Quality bread wheat and root and root rot diseases (RRRD) in the conditions of spring irrigated land in Değirmenli of Sarayönü District of Konya Province in 2016-2017 growing season. The soil samples were taken from the top layer of 0-30 $\mathrm{cm}$ and some physical and chemical analyzes were carried out in the Soil Fertilizer Plant Nutrition Research Laboratory of the Faculty of Agriculture of Selcuk University, on October 19, 2016.

The experiment was carried out in randomized block design with four replications in 3 blocks in total 72 parcels. A total of 72 parcels were planned to be 3 blocks next to each of the 24 parcels with $2.5 \mathrm{~m}$ width and $6 \mathrm{~m}$ length. Wheat seeds with pesticide were planted in each plot with $450 \mathrm{seed} \mathrm{m}^{-2}$ sowing norm on October 30, 2016. $13 \mathrm{~kg}$ of DAP was applied by drilling in to bottom in the sowing. Half of the amount of $\mathrm{N}$ planned to be given in the trial during the period of brother hood with area in March, the remaining half of the period of retention, in April, ammonium sulfate fertilizer was given.

During the production season, $100 \mathrm{~kg} \mathrm{~N} \mathrm{ha}^{-1}$ was to tally applied to the first of the blocks, $150 \mathrm{~kg} \mathrm{~N}^{-1} \mathrm{was}^{-1}$ applied to the second and $200 \mathrm{~kg} \mathrm{~N}^{-1}$ was applied to the third. The $0,5,10,20,40$ and $60 \mathrm{~kg} \mathrm{CS}^{-1}$ hazes were pulverized as sufficient solution in to the plots having four replicated prepared in the blocks between the brother hood and stalking period.

The highest grain yield in wheat $\left(4.050 \mathrm{~kg} \mathrm{ha}^{-1}\right)$ was taken from $150 \mathrm{~kg} \mathrm{~N} \mathrm{ha}^{-1}$ and $40 \mathrm{~kg} \mathrm{CS} \mathrm{ha}^{-1}$. The highest yield was obtained as $\mathrm{N}$ needed and RRRD did not occur. The lowest grain yield $\left(3.020 \mathrm{~kg} \mathrm{ha}^{-1}\right)$ was taken from the plot where CS was not applied in the $100 \mathrm{~kg}$ of $\mathrm{N} \mathrm{ha}^{-1}$ and from the plot where $5 \mathrm{~kg} \mathrm{CS} \mathrm{ha}^{-1}$. The $\mathrm{N}$ doze applied in these plots could not meet the need of the plant. Besides, grain yield was lower than the other plots because of the occurrence of RRRD in these plots. The yield average $\left(3.370 \mathrm{~kg} \mathrm{ha}^{-1}\right)$ did not increase gradually and low grain yield was obtained according to $150 \mathrm{~kg} \mathrm{~N} \mathrm{ha}^{-1}$ by more $\mathrm{N}$ application $\left(200 \mathrm{~kg} \mathrm{~N} \mathrm{ha}^{-1}\right)$ which is more than need of the wheat.

The lowest RRRD scalevalue (0) was obtained from the application of 20, 40 and $60 \mathrm{~kg} \mathrm{CS} \mathrm{ha}^{-1}$ in $100 \mathrm{~kg} \mathrm{~N}$ $\mathrm{ha}^{-1}$ application and no diseases were observed in these plots. The highest RRRD scale value (3) was observed at the dozes of 0,5 and $10 \mathrm{~kg} \mathrm{CS} \mathrm{ha}^{-1}$ in $200 \mathrm{~kg} \mathrm{~N} \mathrm{ha}^{-1}$. It was observed that as the doze of CS increased, the scale of RRRD scale decreased, and as the $\mathrm{N}$ dose increased, the value of RRRD scale increased. As the N doze increased, the cell structure of the plant has grown rapidly. Therefore, the rapidly developing cell structure was susceptible to the disease and hence as $\mathrm{N}$ doze increased, RRRD increased. In the CS applications, when the application doze of CS increased, the value of RRRD scale decreased and it was understood that the disease was stopped at $40 \mathrm{~kg}$ CS ha-1.

The highest plant height $(58 \mathrm{~cm})$ was obtained from $40 \mathrm{~kg} \mathrm{CS} \mathrm{ha}^{-1}$ in $200 \mathrm{~kg} \mathrm{~N} \mathrm{ha}^{-1}$ block and the lowest plant height $(49 \mathrm{~cm})$ was obtained from the plot not applied CS in the $100 \mathrm{~kg} \mathrm{~N} \mathrm{ha}^{-1}$. The highest number of spikes (660) in $\mathrm{m}^{2}$ wastakenfrom $200 \mathrm{~kg} \mathrm{~N} \mathrm{ha}^{-1}$ and $60 \mathrm{~kg} \mathrm{CS} \mathrm{ha}^{-1}$, and the lowest spike number (492) from $100 \mathrm{~kg} \mathrm{~N} \mathrm{ha}^{-1}$ and CS were not applied. The highest grain number (28) was obtained from $150 \mathrm{~kg} \mathrm{~N} \mathrm{ha}^{-1}$ and $40 \mathrm{~kg} \mathrm{CS} \mathrm{ha}^{-1}$, and the lowest grain number (21) was obtained from $150 \mathrm{~kg} \mathrm{~N}^{-1}$ and CS was not use plot. The highest thousand grain weight (45.00 g) was taken from $150 \mathrm{~kg} \mathrm{~N} \mathrm{ha}^{-1}$ and $40 \mathrm{~kg} \mathrm{CS} \mathrm{ha}^{-1}$, and the lowest one thousand grain weight (36.25 g) was taken from $100 \mathrm{~kg} \mathrm{~N} \mathrm{ha}^{-1}$ and BS not applied plot. The highest protein ratio (12.88\%) was obtained from $40 \mathrm{~kg} \mathrm{CS} \mathrm{ha}^{-1}$ with $150 \mathrm{~kg} \mathrm{~N} \mathrm{ha}^{-1}$ and the lowest protein ratio (7.35\%) from $100 \mathrm{~kg} \mathrm{~N} \mathrm{ha}^{-1}$ and CS was not used plot.

In the fight against RRRD, in our study, the results of CS applications are investigated together with $\mathrm{N}$ applications, RRRD was not seen in the 20,40 and $60 \mathrm{~kg} \mathrm{CS} \mathrm{ha}^{-1}$ in the $100 \mathrm{~kg} \mathrm{~N} \mathrm{ha}^{-1}$, in 40 and $60 \mathrm{~kg} \mathrm{CS} \mathrm{ha}^{-1}$ in the 150 and $200 \mathrm{~kg} \mathrm{~N} \mathrm{ha}^{-1}$. RRRD decreased as CS dozes increased until $20 \mathrm{~kg} \mathrm{CS} \mathrm{ha}^{-1}$ in the $100 \mathrm{~kg} \mathrm{~N} \mathrm{ha}^{-1}, 40 \mathrm{~kg}^{-}$

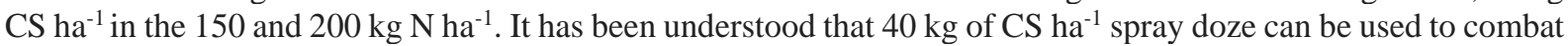
RRRD between brotherhood and stalking period. $150 \mathrm{~kg} \mathrm{~N} \mathrm{ha}^{-1}$ doze may be recommended for high yield and yield components in similar wheat, soil and climate conditions. 
Buğday dünyada ve ülkemizde en çok üretilen ve ülkelerin beslenme, ticaret ve ekim nöbeti sistemlerinde vazgeçilmez bir kültür bitkisidir. Dünya nüfusu ile tarımsal üretim ve gıdanın aynı oranda artmaması açlık sorununu ortaya çıkarmaktadır. Akdeniz ve Balkan ülkelerinin ana gıda maddesi buğday ve buğday ürünleridir.

Buğday, dünya besin kalorisinin yaklaşık \%20'sini karşılamaktadır (Wiese, 1991). Ülkemizde kişi başına buğday tüketimi $250 \mathrm{~kg} / \mathrm{y}$ ll, kişi başına günlük ekmek tüketimi ise $360 \mathrm{~g}$ civarındadır (Anonim, 2016a). İnsan beslenmesinde dünyada en çok kullanılan kültür bitkileri arasında yer alan ekmeklik buğday (TriticumaestivumL.) ve makarnalık buğday (Triticum durum Desf.) ülkemizde ve gelişmekte olan ülkelerde temel besin kaynaklarını oluşturmaktadır. Tarıma dayalı sanayide, gıda sanayisinin alt dalı olan un ve unlu mamuller sanayisine hammadde olmasının yanı sıra kepek, saman vb. olarak da hayvancılık sektörünün önemli bir unsuru olan buğday, strateji uzmanlarına göre 21. yüzyılın en önemli jeo-ekonomik gücüdür (Koca, 1999).

Buğdaya karşı artan talepleri karşılayabilmek için tarım yapılan alanları çeşitli nedenlerle günden güne azalan ülkelerde esas yapılması gereken birim alandan alınan ürün miktarını artırmaktır. Buğday kök ve kök boğazı fungal hastalıkları verimi sınırlayan en önemli faktörler arasında yer almaktadır. Bitki kök sağ lığı, bitkinin ortamdaki su ile besin maddelerini en iyi şekilde alması ve değişik çevre koşullarına uyumu açısından önemlidir. Köklerin hastalıklı olması halinde, kök yoğunluğu ve derinliği azalmakta, bitkilerin kullanabildiği toprak derinliği daha yüzeysel kalmakta, bundan dolayı bitki topraktaki su ve besin maddelerini yeterince alamamakta ve sonuçta önemli verim kayıpları meydana gelebilmektedir (Cook, 1992).Kök ve kök boğazı çürüklüğü hastalık etmenlerinin uygun ortam bulduklarında kısa sürede inokulum üretebilmeleri hem toprak hem de tohum kökenli olmaları, tohum ve bitki artıkları ile taşınmaları, toprakta uzun yıllar yaşayabilmeleri ve bir veya birkaç etmenin aynı anda bir arada bulunması özelliklerinden dolayı bu etmenler ile mücadele oldukça zordur. Kök ve kök boğazı hastalık etmeni funguslar toprakta bitki artıkları üzerinde iki yıldan fazla canlılıklarını sürdürebildikleri bildirilmektedir (Anonim, 2016b).

Türkiye'de kullanılan gübreler arasında azotlu gübreler ilk sırayı (\%64.1) almaktadır. Çünkü söz konusu toprakların organik madde içerikleri düşük olup bitkilerin azot istekleri daha fazladır. Ülkemizde kullanılan azotlu gübrelerin \%50'si tahılların gübrelenmesinde tüketilmektedir. Toprakta azotun gereğinden fazla bulunması birim alanda başak sayısının artmasına ancak başaktaki tane sayısının azalmasına yol açmaktadır. Aşırı azot ile vejetatif gelişme hızlanırken tane verimi azalır. Fazla azot bitkinin yatmasına ve dolayısıyla ürün kaybına sebep olmaktadır (Kacar ve Katkat, 2007). Kuzeydoğu Almanya'nın kumlu topraklarında yürütülen uzun süreli organik ve mineral azotlu gübrelemenin buğdayda verim ve kaliteye önemli bir etki yaptığı ortaya konulmuştur. Ayrıca bu denemede yer alan Ares ekmeklik buğday çeşidinin kalite özellikleri mineral azot gübrelemesinden etkilenmiş ve iyi bir ekmeklik kalitesini elde etmek için 11-16 $\mathrm{kg} \mathrm{N} \mathrm{da}^{-1}$ uygulamasına ihtiyaç bulunduğu bildirilmiştir (Ellmer ve ark., 2001).

Bu çalışma ile Konya İli, Sarayönü İlçesi’nde kök ve kök boğazı çürüklüğü hastalığı bulaşık, sulu tarla koşullarında yetiştirilen ekmeklik buğdayda, toprağa artan dozlarda bakır sülfat ve azot uygulamalarının verim ile kök ve kök boğazı çürüklüğü hastalığına etkilerini araştırmak, en yüksek verim için kullanılması gereken bakır sülfat ve azot dozlarını belirlemek, elde edilen bilgi ile buğday üreticilerine ve ülke ekonomisine katkı sağlamak amaçlanmıştır. Zira ülkemizin tahıl ambarı Konya'da giderek artan kök ve kök boğazı çürüklüğü hastalığının önlenmesine dair bakır sülfat ve azotlu gübre dozlarının etkileri hemen hemen hiç araştırılmamıştır.

\section{Materyal ve Yöntem}

$\mathrm{Bu}$ çalışma, artan dozlarda bakır sülfat $\left(\mathrm{BS} ; \mathrm{CuSO}_{4} .5 \mathrm{H}_{2} \mathrm{O} ; \% 35 \mathrm{Cu}\right.$ ) ve azot(N) uygulamalarının Quality çeşidi ekmeklik buğdayda verim ve verim unsurları ile kök ve kök boğazı çürüklüğü hastalığına (KKBÇH) etkilerini tespit etmek amacıyla 2016-2017 üretim sezonunda Konya'nın Sarayönü İlçesi'nin Değirmenli Mahallesi’nde 0 ada 307 parsel numaralı bir çiftçi tarlasında yağmurlama sulamalı koşullarında yapılmıştır.

Tarlada buğday ekimi öncesinde 19 Ekim 2016 tarihinde verimlilik analizleri için 0-30 cm'lik üst katmanı temsilen toprak örnekleri alınarak Selçuk Üniversitesi Ziraat Fakültesi Toprak Gübre Bitki Besleme Araştırma Laboratuvarı'nda bazı fiziksel ve kimyasal analizler yapılmıştır. Analiz sonuçlarına göre (Çizelge 1), deneme toprağ killi tın tekstürlü, hafif alkalinreaksiyonlupH'll, tuzsuz, orta kireçli ve yüksek organik maddelidir. Bor çok az, azot, demir ve mangan az, potasyum, magnezyum, çinko ve bakır yeterli, fosfor ve kalsiyum ise fazladır. Ancak ekstrakte edilebilir kalsiyumun, potasyum ve magnezyuma, magnezyumun da potasyuma oranlarının yüksek olmas1 istenmeyen bir durumdur (Jokinen, 1981). 
Denemede Quality çeşidi ekmeklik buğday yetiştirilmiştir. Quality çeşidi buğday 2014 yılında TMO tarafından 1. Grup Ekmeklik olarak bareme alınmıştır. Kırmızı, sert ve iri taneli, orta erkenci bir çeşit olup kısa boyludur. Bin tane ağırlığı 40-44 g, hektolitre ağırlığı 80-82 g civarındadır. Ekmeklik kalitesi iyi, hayli yüksek bir protein ve enerji içeriğine sahiptir.

Deneme, tesadüf bloklarında bölünmüş parseller deneme desenine göre dört tekerrürlü olarak 3 blokta, toplamda 72 parselde yürütülmüştür. $2.5 \mathrm{~m}$ eninde ve $6 \mathrm{~m}$ uzunluğundaki $\left(15 \mathrm{~m}^{2}\right) 24$ parselden yan yana 3 tane blok olacak şekilde (toplam 72 parsel) planlanmıştır. Ana parsellere $\mathrm{N}\left(10 \mathrm{~kg} \mathrm{~N} \mathrm{da}^{-1}, 15 \mathrm{~kg} \mathrm{~N} \mathrm{da}{ }^{-1} \mathrm{ve}_{20 ~ \mathrm{~kg} \mathrm{~N} \mathrm{da}^{-}}\right.$ $\left.{ }^{1}\right)$, alt parsellere ise BS $\left(0,0.5,1,2,4\right.$ ve $\left.6 \mathrm{~kg} \mathrm{BSda}^{-1}\right)$ dozları her blok içinde 4 tekerrürlü olarak kardeşlenme ile sapa kalkma dönemi arasında yeterli çözelti halinde bitkilere pülverize edilmiştir.

Çizelge 1.Deneme toprağının bazı fiziksel ve kimyasal analiz sonuçları

Table 1.Some physical and chemical analysis results of testing soil

\begin{tabular}{|c|c|c|c|}
\hline Parametreler & Sonuçlar & Yorumlar & Normal değerler \\
\hline Tekstür sınıfı & Killi tın & Normal, iyi & Tinl1 $^{1}$ \\
\hline $\mathrm{pH}(1: 2.5 \mathrm{t}: \mathrm{s} ; \mathrm{pH}$ metre $)$ & 7.73 & Hafif alkalin & $6.5-7.5^{2}$ \\
\hline $\mathrm{EC}\left(1: 5 \mathrm{t}: \mathrm{s}, \mu \mathrm{S} \mathrm{cm}^{-1}, \mathrm{EC}\right.$ metre $)$ & 234 & Tuzsuz, iyi & $<400^{2}$ \\
\hline $\begin{array}{l}\text { Kireç (toplam } \mathrm{CaCO}_{3} ; \% \\
\text { ScheiblerKalsimetresi) }\end{array}$ & 11.8 & Orta kireçli & $3-7^{1}$ \\
\hline Organik madde (\%, Smith-Weldon) & 3.53 & Yüksek, iyi & $3-6^{1}$ \\
\hline Azot $\left(\mathrm{NH}_{4}-\mathrm{N}+\mathrm{NO}_{3}-\mathrm{N} ; \mathrm{mg} \mathrm{kg}^{-1}, \mathrm{Kjeldahl}\right)$ & 14.6 & $\mathrm{Az}$ & $50-500^{3}$ \\
\hline Fosfor (yar. P (mg kg ${ }^{-1}$, Olsen) & 47.9 & Fazla & $8-25^{3}$ \\
\hline Potasyum (ekst. edil. $\mathrm{K}, \mathrm{mg} \mathrm{kg}^{-1}, \mathrm{NH}_{4} \mathrm{OAc}, \mathrm{ICP}$ ) & $192(0.49 \mathrm{me} / 100 \mathrm{~g})$ & Yeterli & $110-290^{3}$ \\
\hline $\begin{array}{l}\text { Kalsiyum (ekst. edil. } \mathrm{Ca}, \mathrm{mg} \mathrm{kg}^{-1}, \mathrm{NH}_{4} \mathrm{OAc} \text {, } \\
\text { ICP) }\end{array}$ & $\begin{array}{c}6.981(34.90 \mathrm{me} / 100 \\
\mathrm{g})\end{array}$ & Yüksek & $1.150-3.500^{3}$ \\
\hline $\begin{array}{l}\text { Magnezyum (ekst. ed. } \mathrm{Mg}, \mathrm{mg} \mathrm{kg}^{-1}, \mathrm{NH}_{4} \mathrm{OAc} \text {, } \\
\text { ICP) }\end{array}$ & $401(3.34 \mathrm{me} / 100 \mathrm{~g})$ & Yeterli & $160-480^{3}$ \\
\hline Sodyum (ekst. edil. $\left.\mathrm{Na}, \mathrm{mg} \mathrm{kg}^{-1}, \mathrm{NH}_{4} \mathrm{OAc}, \mathrm{ICP}\right)$ & $29(0.12 \mathrm{me} / 100 \mathrm{~g})$ & - & - \\
\hline Değişebilir sodyum yüzdesi & 0.31 & $\begin{array}{l}\text { Sodiklik sorunu } \\
\text { yok }\end{array}$ & $<15^{1}$ \\
\hline Demir (yarayışlı Fe, mg kg ${ }^{-1}$, DTPA, ICP) & 1.26 & $\mathrm{Az}$ & $4.5-10^{4}$ \\
\hline Çinko (yarayışlı Zn, mg kg ${ }^{-1}$, DTPA, ICP) & 0.79 & Çok az & $0.7-2.4^{3}$ \\
\hline Mangan (yarayışlı Mn, mg kg ${ }^{-1}$, DTPA, ICP) & 1.41 & $\mathrm{Az}$ & $14-50^{3}$ \\
\hline Bor (yarayışlı B, mg kg-1 , Mannitol, ICP) & 0.06 & $\mathrm{Az}$ & $1.0-2.4^{5}$ \\
\hline Bakır (yarayışlı Cu, mg kg-1, DTPA, ICP) & 0.55 & Yeterli & $>0.2^{6}$ \\
\hline $\mathrm{Ca} / \mathrm{K}$ (me/100 g birimleri ile) & 71.22 & Yüksek & $12^{7}$ \\
\hline $\mathrm{Ca} / \mathrm{Mg}$ (me/100 g birimleri ile) & 10.44 & Yüksek & $6^{7}$ \\
\hline $\mathrm{Mg} / \mathrm{K}$ (me/100 g birimleri ile) & 6.81 & Yüksek & $2^{7}$ \\
\hline
\end{tabular}

Mibzerle her parsele 450 tohum $/ \mathrm{m}^{2}$ ekim normunda ilaçlı Quality ekmeklik buğday tohumları 30 Ekim 2016 tarihinde ekilmiştir.Ekimde mibzerle tabana dekara $13 \mathrm{~kg}$ DAP (Diamonyum fosfat; 18.46.0) verilmiştir. Böylece ekimde $6 \mathrm{~kg} \mathrm{P}_{2} \mathrm{O}_{5}$ ve $2.34 \mathrm{~kg} \mathrm{~N} \mathrm{da}{ }^{-1}$ uygulanmıştır. Denemede verilmesi planlanan diğer azot miktarının yarısı kardeşlenme döneminde, mart ayında üre (\%46 N), kalan yarısı da sapa kalkma döneminde, Nisan ayında amonyum sülfat $(\% 21 \mathrm{~N})$ gübresi ile verilmiştir. Toprak analiz sonuçlarına göre eksik olan mangan ve bor Nisan ayında ilk yağmurlama sulama ile her parsele $1 \mathrm{~kg}$ mangan sülfat $\left(\mathrm{MnSO}_{4} .3 \mathrm{H}_{2} \mathrm{O} ; \% 27 \mathrm{Mn}\right) \mathrm{da}^{-1}$ ve $0.5 \mathrm{~kg}$ Etidot67 (\%20.8 bor) $\mathrm{da}^{-1}$ dozlarında uygulanmıştır.

Her parselin ortasındaki $1 \mathrm{~m}^{2}$ 'lik kısım el ile hasat ve harman edilerek, taneler hassas terazide tartılıp $\mathrm{kg} \mathrm{da}^{-1}$ olarak hasatta verim belirlemesi hesaplanmıştır. Her parselden tesadüfi olarak seçilen 10 bitkinin ana saplarında, toprak yüzeyinden başağın üst başakçık ucuna kadar (kılçıklar hariç) olan yükseklik cm cinsinden bitki boyu 
ölçülmüştür (Yürür ve ark., 1981). Her parselin ortasındaki 2 sırada 1 m’de bulunan başak sayısının m²'deki başak sayısına çevrilmesi ilem² ${ }^{2}$ de başak sayısı(adet) bulunmuştur (Tosun ve Yurtman, 1973).Her parselde tespit edilen 10 bitkinin ana sapındaki başaklar elle ayrı ayrı hasat edilip taneler sayılarak ortalamaları alınıp adet olarak başakta tane sayısı belirlenmiştir (Yürür ve ark., 1981).Her parselden alınan tanelerde dört defa 100 tane sayılıp $0.001 \mathrm{~g}$ hassasiyetli terazide tartılarak ortalamaları alınıp 10 ile çarpılarak g cinsinden bin tane ağırlığı ifade edilmiştir (Genç, 1974).Her parselden elde edilen tane verimlerinin aynı alandan elde edilen 'sap+tane' verimine oranı \% olarak hasat indeksi hesaplanmıştır (Çölkesen ve ark., 1993).Her parselin ortasındaki $1 \mathrm{~m}^{2}$ 'lik alandaki bitkilerin hastalık şiddetine göre, kök ve kök boğazı çürüklüğü hastalığı değerlendirme skalasına göre skala değeri belirlenmiştir. Tanede protein analizi Selçuk Üniversitesi Ziraat Fakültesi Toprak, Gübre ve Bitki Besleme Araştırma Laboratuvarı'ndaH $\mathrm{SO}_{4}+\mathrm{H}_{2} \mathrm{O}_{2}$ ile yaş yakılan örneklerde mikro Kjeldahl yöntemi ile (Bayrakl1, 1987) belirlenen $\mathrm{N}$ değerlerinden tanenin protein oranları hesaplanmıştır.

Uygulamalara karşı elde edilen verim ve verim unsurları değerleri Tesadüf bloklarında bölünmüş parseller deneme desenine göre MSTAT-C istatistiksel paket programında varyans analizine tabi tutulmuş, önemli çıkan muamelelerde ise aynı program yardımıyla Duncan grupları belirlenmiştir (Yurtsever, 1984). Ayrıca kök ve kök boğazı çürüklüğü istatistikleri her bir faktörün bir seviyesinde diğer faktörün tüm seviye rank ortalamaları Kruskall Wallis Testi yardımıyla karşılaştırılmıştır. Ele alınan skor özelliği bakımından istatistik analiz Minitab-16 paket programıyla yapılmıştır. Analiz sonucu grupların rank ortalamaları arasındaki fark Bonferroni-Dunn çoklu karşılaştırma testi yardımıyla belirlenmiştir.

\section{Bulgular ve Tartışma}

Araştırmada artan miktarlarda BS (bakır sülfat) ve N (azot) uygulamalarının ekmeklik buğdayda verim ve verim unsurları ile KKBÇH (kök ve kök boğazı çürüklüğü hastalığı)'na etkileri ile ilgili açıklamalar aşağıda alt başlıklar halinde verilmiştir.

\section{Uygulamaların Buğdayda Tane Verimine Etkileri}

Artan miktarlarda BS ve N uygulamalarının ekmeklik buğdayda verim ve verim unsurlarına etkileri ile ilgili varyans analiz sonuçları Çizelge 2'de, uygulamaların buğdayda KKBÇH'na etkisi ile ilgili varyans analiz sonuçları Çizelge 3'de, verim ve verim unsurlarına ilişkin ortalama değerler ve oluşan Duncan grupları ise Çizelge 4'de verilmiştir.

Çizelge 2.Artan miktarlarda bs ve n uygulamalarının buğdayda verim ve verim unsurlarına etkileri ile ilgili varyans analiz sonuçları

Table 2.The results of variance analysis regardingtheeffects of increasingamount of cs and $\mathrm{n}$ applications on yieldandyield components of wheat

\begin{tabular}{|c|c|c|c|c|c|c|c|c|}
\hline \multirow[t]{2}{*}{ Varyans kaynağı } & \multirow[t]{2}{*}{ S.D. } & \multicolumn{7}{|c|}{ Kareler ortalaması } \\
\hline & & $\begin{array}{c}\text { Tane } \\
\text { verimi }\end{array}$ & $\begin{array}{l}\text { Bitki } \\
\text { boyu }\end{array}$ & $\begin{array}{l}\mathrm{m}^{2} \mathrm{de} \\
\text { başak } \\
\text { sayısı }\end{array}$ & $\begin{array}{c}\text { Başakta } \\
\text { tane } \\
\text { sayısı }\end{array}$ & $\begin{array}{c}\text { Bin } \\
\text { tane } \\
\text { ağırlığı }\end{array}$ & $\begin{array}{l}\text { Hasat } \\
\text { indeksi }\end{array}$ & $\begin{array}{c}\text { Protein } \\
\text { oranı }\end{array}$ \\
\hline Genel & 71 & -- & -- & -- & -- & -- & -- & -- \\
\hline Tekerrür & 3 & 16555 & 18.5 & 20024 & 44.79 & 13.74 & 90.82 & 0.27 \\
\hline $\mathrm{N}$ uygulaması & 2 & $17947 *$ & $\begin{array}{c}123.6^{*} \\
*\end{array}$ & 9508 & 5.38 & $117.9 *$ & $\begin{array}{c}156.54 \\
*\end{array}$ & $\begin{array}{c}43.06^{*} \\
*\end{array}$ \\
\hline Hata & 6 & 2794 & 5.09 & 10215 & 1.22 & 12.87 & 35.30 & 1.39 \\
\hline BS uygulaması & 5 & 4626 & 22.6 & 10326 & 16.28 & 14.11 & 7.16 & $\begin{array}{c}14.10^{*} \\
*\end{array}$ \\
\hline $\begin{array}{l}\text { NxBSinteraksiyon } \\
\mathrm{u}\end{array}$ & 10 & 1218 & 7.89 & 3847 & 11.12 & 8.17 & 15.42 & $8.96 * *$ \\
\hline Genel Hata & 45 & 2719 & 18.8 & 9870 & 8.01 & 6.36 & 19.48 & 1.22 \\
\hline
\end{tabular}

$* . \mathrm{p}<0.05, * * . \mathrm{p}<0.01$

Buğdayda Tane verimine sadece $\mathrm{N}$ uygulamasının etkisi \%5 düzeyinde önemli çıkmıştır (Çizelge 2). Tane verimi üzerine $\mathrm{N}$ uygulamalarının \%5 düzeyinde önemli çıkması tane veriminin farklı miktarlarda $\mathrm{N}$ uygulamasına bağlı olarak değiştiğini göstermektedir. 
Çizelge 4'den de görüldüğü gibi oluşturulan N bloklarındaki en yüksek tane verimi ortalaması $\left(374 \mathrm{~kg} \mathrm{da}^{-1}\right)$ $15 \mathrm{~kg} \mathrm{~N} \mathrm{da}^{-1}$ uygulamasından, en düşük tane verimi ortalaması ise $\left(320 \mathrm{~kg} \mathrm{da}^{-1}\right) 10 \mathrm{~kg} \mathrm{~N} \mathrm{da}^{-1}$ uygulamasından elde edilmiştir. Buğdayın ihtiyaç duyduğ $\mathrm{N}$ miktarından daha fazla $\mathrm{N}\left(20 \mathrm{~kg} \mathrm{~N} \mathrm{da}^{-1}\right)$ uygulaması ile verim ortalaması (337 $\mathrm{kg} \mathrm{da}^{-1}$ ) giderek artmayıp $15 \mathrm{~kg} \mathrm{~N} \mathrm{da}^{-1}$ dozuna göre düşük tane verimi ortalaması elde edilmiştir. $10 \mathrm{~kg} \mathrm{~N} \mathrm{da}^{-}$ ${ }^{1}$ dozu bitkinin $\mathrm{N}$ ihtiyacından daha düşük bir doz olduğundan bitkinin $\mathrm{N}$ ihtiyacı karşılanamamış bitkinin vejetatif aksamının normal gelişebilmesi için yeterli olmamıştır, $20 \mathrm{~kg} \mathrm{~N} \mathrm{da}^{-1}$ dozunda ise bitkinin vejetatif aksamı fazla azot uygulamasından dolayı normalden fazla ve hızlı büyümüş dolayısıyla verim değerleri $15 \mathrm{~kg} \mathrm{~N}^{-}$ ${ }^{1}$ uygulamasına göre düşük çıkmıştır, $15 \mathrm{~kg} \mathrm{~N} \mathrm{da}^{-1}$ dozu ise birçok araştırmacının (Sağlam, 1999; Gezgin, 2003; Kacar ve Katkat, 2007) belirttiği gibi buğday için optimum bir dozdur. Gökmen ve ark. (2008), makarnalık buğdayda iki yıl süreyle yaptıkları bir araştırmada en yüksek tane verimini her iki yıl içinde amonyum nitrat (\%33 N) gübresinin $18 \mathrm{~kg} \mathrm{~N} /$ da dozu ile elde etmişlerdir.

Çizelge 3. Artan miktarlarda BS ve N uygulamalarının buğdayda kkbçh'na etkileri ile ilgili varyans analiz sonuçları

Table 3.Results of variance analysis related to effects increasing amount of CS and N applications on rrcrd of wheat

\begin{tabular}{|c|c|c|c|c|c|}
\hline $\operatorname{Azot}\left(\mathrm{kg} \mathrm{da}^{-1}\right)$ & $\mathrm{BS}\left(\mathrm{kg} \mathrm{da}^{-1}\right)$ & Tekerrür & $\begin{array}{c}\text { Hastalık } \\
\text { Skalası } \\
\end{array}$ & $\begin{array}{c}\text { Ortalama } \\
\text { Rank } \\
\end{array}$ & P değeri \\
\hline \multirow[t]{7}{*}{10} & 0 & 4 & 3 & $22.50 \mathrm{a}$ & $0.0001 * *$ \\
\hline & 0.5 & 4 & 1 & $16.50 \mathrm{~b}$ & \\
\hline & 1 & 4 & 1 & $16.50 \mathrm{~b}$ & \\
\hline & 2 & 4 & 0 & $6.50 \mathrm{c}$ & \\
\hline & 4 & 4 & 0 & $6.50 \mathrm{c}$ & \\
\hline & 6 & 4 & 0 & $6.50 \mathrm{c}$ & \\
\hline & & Ort. & $0.83 A$ & & \\
\hline \multirow[t]{7}{*}{15} & 0 & 4 & 3 & $20.50 \mathrm{a}$ & $0.0001 * *$ \\
\hline & 0.5 & 4 & 3 & $20.50 \mathrm{a}$ & \\
\hline & 1 & 4 & 1 & $12.50 \mathrm{~b}$ & \\
\hline & 2 & 4 & 1 & $12.50 \mathrm{~b}$ & \\
\hline & 4 & 4 & 0 & $4.50 \mathrm{c}$ & \\
\hline & 6 & 4 & 0 & $4.50 \mathrm{c}$ & \\
\hline & & Ort. & $1.33 \mathrm{~B}$ & & \\
\hline \multirow[t]{6}{*}{20} & 0 & 4 & 3 & $18.50 \mathrm{a}$ & $0.0001 * *$ \\
\hline & 0.5 & 4 & 3 & $18.50 \mathrm{a}$ & \\
\hline & 1 & 4 & 3 & $18.50 \mathrm{a}$ & \\
\hline & 2 & 4 & 1 & $10.50 \mathrm{~b}$ & \\
\hline & 4 & 4 & 0 & $4.50 \mathrm{c}$ & \\
\hline & 6 & 4 & 0 & $4.50 \mathrm{c}$ & \\
\hline
\end{tabular}

\footnotetext{
**. p<0.01. Aynı sütunda aynı harfle gösterilen değerler arasındaki fark istatistiksel olarak önemsizdir.
}

Uygulama parsellerine bakıldığında(Çizelge 4), parsellerdeki en yüksek tane verimi (405 kg da $\left.\mathrm{a}^{-1}\right) 15 \mathrm{~kg} \mathrm{~N} \mathrm{da}^{-}$ ${ }^{1}$ ve 4 kg BS da ${ }^{-1}$ uygulamasından alınmıştır. Bu parsele bitkinin ihtiyacı kadar $\mathrm{N}$ uygulandığından ve KKBÇH oluşmadığından en yüksek verim elde edilmiştir. En düşük tane verimi (302 $\left.\mathrm{kg} \mathrm{da}^{-1}\right)$ ise $10 \mathrm{~kg} \mathrm{~N} \mathrm{da}^{-}$ ${ }^{1}$ uygulamasındaki BS uygulanmayan ve $0.5 \mathrm{~kg} \mathrm{BS} \mathrm{da}^{-1}$ uygulanan parsellerden alınmıştır. Bu parsellerde uygulanan $\mathrm{N}$ dozu bitkinin ihtiyacını karşılayamamış, ayrıca bu parsellerde $\mathrm{KKBÇH} \mathrm{görüldüğünden} \mathrm{tane} \mathrm{verimi} \mathrm{diğer}$ parsellere göre daha düşük oluşmuştur.

Bu sonuçlara göre de toprak ve bitki analizlerine dayalı gübreleme programlarının yapılmasının gerekliliği ortaya çıkmaktadır. Bununla birlikte gübre dozları belirlenirken özellikle hedeflenen verimin dikkate alınarak 
gübre uygulamaları yapılmalıdır. Optimumdan fazla azotlu gübre uygulaması verim ve kaliteyi düşürdüğü gibi uygulanan fazla gübre de çevreyeve ülke ekonomisine zarar verebilmektedir.

KKÇH'nın durduğu, $10 \mathrm{~kg} \mathrm{~N} \mathrm{da}{ }^{-1}$ uygulamasında $2 \mathrm{~kg} \mathrm{BS} \mathrm{da}^{-1} \mathrm{dozu}, 15 \mathrm{~kg} \mathrm{~N} \mathrm{da}{ }^{-1}$ ve $20 \mathrm{~kg} \mathrm{~N} \mathrm{da}{ }^{-1}$ uygulamalarında ise $4 \mathrm{~kg} \mathrm{BS} \mathrm{da}{ }^{-1}$ dozuna kadar uygulanan BS dozları arttıkça KKBÇHazalmıştır (Çizelge 4). KKBÇHazaldıkça tane verim değerlerinde artışlar meydana gelmiştir. Birçok araştırmacının da (Cook, 1992; Stubbs et al., 1992; Aktaş ve ark., 1999; Hekimhan ve arkadaşları, 2004; Nicol ve ark., 2008) belirttiği gibi, KKBÇH bitkilerde kök sistemine zarar vererek verimi düşürmektedir. KKBÇH bitkinin kök sisteminden su ve besin elementi alımını kısıtlayıcı etki yaptığından buğday bitkisinde tane verim değeri de azalmıştır. Fakat KKBÇH tedavi edildikçe buğday bitkisinin kök sisteminden su ve besin elementi alımı arttıkça buğday bitkisinin gelişimi de artmıştır. Bu yüzden tane verimi hastalık şiddeti azaldıkça artmış olabilir.

Çizelge 4. Artan miktarlarda BS ve N uygulamalarının verim ve verim unsurları ile KKBÇH'na etkileri ve duncan grupları

Table4.The results of variance analysis regarding the effects of increasing amount of CS and N applications on yield components and RRCRD. Duncan groups

\begin{tabular}{|c|c|c|c|c|c|c|}
\hline $\begin{array}{l}\mathbf{N} \\
\left(\mathrm{kg} \mathrm{da}^{-1}\right)\end{array}$ & $\begin{array}{l}\text { BS } \\
\left(\mathrm{kg} \mathrm{da}^{-1}\right)\end{array}$ & & $\begin{array}{l}\text { Tane verimi } \\
\qquad\left(\mathrm{kg} \mathrm{da}^{-1}\right)\end{array}$ & $\begin{array}{l}\text { Hastalık skala } \\
\text { değerleri (0-7) }\end{array}$ & $\begin{array}{l}\text { Bitki boyu } \\
\text { (cm) }\end{array}$ & $\begin{array}{c}\text { m }^{29} \text { de başak } \\
\text { sayısı } \\
\text { (adet) }\end{array}$ \\
\hline \multirow{7}{*}{10} & 0 & & $302 *$ & $3 a$ & 49 & 492 \\
\hline & 0.5 & & 302 & $1 \mathrm{~b}$ & 52 & 595 \\
\hline & 1 & & 340 & $1 \mathrm{~b}$ & 54 & 592 \\
\hline & 2 & & 343 & $0 \mathrm{c}$ & 54 & 590 \\
\hline & 4 & & 333 & $0 \mathrm{c}$ & 53 & 520 \\
\hline & 6 & & 303 & $0 \mathrm{c}$ & 50 & 575 \\
\hline & & Ort. & $320 \mathrm{~B}$ & $0.83 \mathrm{~A}$ & $52 \mathrm{~B}$ & 561 \\
\hline \multirow{7}{*}{15} & 0 & & 340 & $3 \mathrm{a}$ & 50 & 545 \\
\hline & 0.5 & & 342 & $3 \mathrm{a}$ & 51 & 587 \\
\hline & 1 & & 360 & $1 \mathrm{~b}$ & 52 & 592 \\
\hline & 2 & & 399 & $1 \mathrm{~b}$ & 53 & 600 \\
\hline & 4 & & 405 & $0 \mathrm{c}$ & 55 & 630 \\
\hline & 6 & & 398 & $0 \mathrm{c}$ & 55 & 612 \\
\hline & & Ort & $374 \mathrm{~A}$ & $1.33 \mathrm{~B}$ & $53 \mathrm{AB}$ & 594 \\
\hline \multirow{7}{*}{20} & 0 & & 316 & $3 \mathrm{a}$ & 55 & 547 \\
\hline & 0.5 & & 321 & $3 \mathrm{a}$ & 56 & 575 \\
\hline & 1 & & 326 & $3 a$ & 56 & 575 \\
\hline & 2 & & 340 & $1 \mathrm{~b}$ & 57 & 585 \\
\hline & 4 & & 349 & $0 \mathrm{c}$ & 58 & 632 \\
\hline & 6 & & 373 & $0 \mathrm{c}$ & 56 & 660 \\
\hline & & Ort. & 337B & $1.67 \mathrm{C}$ & $56 \mathrm{~A}$ & 596 \\
\hline
\end{tabular}

*: Değerler dört tekerrürün ortalamasıdır. Aynı sütunda aynı harfle gösterilen değerler arasındaki fark istatistiksel olarak önemsizdir. 
Table4.(continuation)

\begin{tabular}{|c|c|c|c|c|c|c|}
\hline $\begin{array}{l}\mathbf{N} \\
\left(\mathbf{k g ~ d a} \mathbf{d a}^{-1}\right)\end{array}$ & $\begin{array}{l}\text { BS } \\
\left(\mathrm{kg} \mathrm{da}^{-1}\right)\end{array}$ & & $\begin{array}{c}\text { Başakta } \\
\text { tanesayısı (Adet) }\end{array}$ & $\begin{array}{c}\text { Bin tane ağırlığı } \\
(\mathrm{g})\end{array}$ & $\begin{array}{c}\text { Hasat indeksi } \\
(\%) \\
\end{array}$ & Protein oranı (\%) \\
\hline \multirow{7}{*}{10} & 0 & & 24 & 36.25 & 48 & $7.35 \mathrm{f}$ \\
\hline & 0.5 & & 26 & 40.00 & 48 & $7.41 \mathrm{f}$ \\
\hline & 1 & & 26 & 40.00 & 48 & $7.52 \mathrm{f}$ \\
\hline & 2 & & 27 & 40.00 & 48 & $9.63 \mathrm{c}-\mathrm{f}$ \\
\hline & 4 & & 26 & 40.00 & 50 & $9.46 \mathrm{def}$ \\
\hline & 6 & & 25 & 38.75 & 46 & $9.51 \mathrm{def}$ \\
\hline & & Ort. & 26 & $39.17 C$ & $48 \mathrm{~A}$ & $8.48 B$ \\
\hline \multirow{7}{*}{15} & 0 & & 21 & 42.50 & 45 & $11.74 \mathrm{a}-\mathrm{d}$ \\
\hline & 0.5 & & 22 & 43.75 & 46 & $12.76 \mathrm{ab}$ \\
\hline & 1 & & 25 & 42.50 & 46 & $9.69 \mathrm{c}-\mathrm{f}$ \\
\hline & 2 & & 26 & 43.75 & 43 & $10.37 \mathrm{~b}-\mathrm{e}$ \\
\hline & 4 & & 28 & 45.00 & 43 & $12.88 \mathrm{a}$ \\
\hline & 6 & & 27 & 43.75 & 43 & $8.55 \mathrm{ef}$ \\
\hline & & Ort. & 25 & $43.54 \mathrm{~A}$ & $44 B$ & $11.00 \mathrm{~A}$ \\
\hline \multirow{7}{*}{20} & 0 & & 26 & 41.87 & 44 & $9.57 \mathrm{c}-\mathrm{f}$ \\
\hline & 0.5 & & 25 & 44.37 & 39 & $9.69 \mathrm{c}-\mathrm{f}$ \\
\hline & 1 & & 26 & 43.12 & 45 & $11.40 \mathrm{a}-\mathrm{d}$ \\
\hline & 2 & & 26 & 42.50 & 44 & $11.97 \mathrm{abc}$ \\
\hline & 4 & & 25 & 41.87 & 41 & $12.87 \mathrm{a}$ \\
\hline & 6 & & 26 & 38.12 & 44 & $7.68 \mathrm{f}$ \\
\hline & & Ort. & 26 & $41.97 B$ & $43 B$ & $10.53 \mathrm{~A}$ \\
\hline
\end{tabular}

*: Değerler dört tekerrürün ortalamasıdır. Aynı sütunda aynı harfle gösterilen değerler arasındaki fark istatistiksel olarak önemsizdir.

\section{Uygulamaların Kök ve Kök Boğazı Çürüklüğü Hastalığına Etkileri}

Artan miktarlarda BS ve N uygulamalarının ekmeklik buğdayda KKBÇH'na etkileri ile ilgili varyans analiz sonuçları Çizelge 3'de, KKBÇH'na ilişkin ortalama değerler ve oluşan Duncan grupları ise Çizelge 4'de verilmiştir.

Varyans analizi sonuçlarına göre (Çizelge 3) 'BS x N' interaksiyonu KKBÇH üzerine istatistiki bakımdan \%1 düzeyinde önemli bulunmuştur. KKBÇH üzerine 'BS x N' interaksiyonunun önemli çıkması KKBÇH'nın artan miktarlarda BS ve N uygulamalarına bağlı olarak değiştiğini göstermektedir.

Çizelge 4'den de görüldüğü gibi, en düşük KKBÇH skala değeri (0) 10 kg N da-1 uygulamasındaki 2, 4 ve 6 $\mathrm{kg} \mathrm{BS} \mathrm{da}{ }^{-1}$ uygulama dozlarından elde edilmiş ve bu parsellerde hastalık görülmemiştir. En yüksek KKBÇH skala değeri (3) $20 \mathrm{~kg} \mathrm{~N} \mathrm{da}^{-1}$ uygulamasındaki $0,0.5 \mathrm{ve} 1 \mathrm{~kg} \mathrm{BS} \mathrm{da}^{-1}$ uygulama dozlarında görülmüştür. BS dozları arttıkça KKBÇH skala değerinin azaldığı, N dozu arttıkça KKBÇH skala değerinin de arttı̆̆ görülmüştür. Bazı araştırıcıların da (Hoffland ve ark., 2000) bildirdiği gibi, dokuda N konsantrasyonu arttıkça bitkiler hastalıklara karşı dayanıksız hale gelmektedirler. Araştırmamızda uygulanan N dozu arttıkça bitkinin hücre yapısı hızla gelişme göstermiştir. Bu yüzden hızlı gelişen hücre yapısı hastalığa karşı hassaslaşmış, dolayısıyla KKBÇH uygulanan N dozu arttıkça etkisini artırmıştır. BS uygulamalarında ise BS uygulama dozu arttıkça KKBÇH skala değeri azalmıştır. Bazı araştırmacıların da (Reis ve ark., 1982; Duffy ve Defag, 1999; Lawrence ve ark., 2007)bildirdiği gibi, bakır, fungal ve bakteriyel hastalıkların (külleme hariç) kontrolünde fungisit olarak kullanılmaktadır. Elde edilen sonuçlara göre ekmeklik buğday bitkisinde $4 \mathrm{~kg} \mathrm{BS} \mathrm{da}{ }^{-1}$ dozunda hastalığın durduğu anlaşılmıştır.

\section{Uygulamaların Bitki Boyuna Etkileri}

Artan miktarlarda BS ve N uygulamalarının ekmeklik buğdayın bitki boyuna etkileri ile ilgili varyans analiz sonuçları Çizelge 2'de, bitki boyuna ilişkin ortalama değerler ve oluşan Duncan grupları ise Çizelge 4'de verilmiştir. Buğdayda bitki boyuna sadece $\mathrm{N}$ uygulamasının etkisi \%1 düzeyinde önemli çıkmıştır (Çizelge 2). Bitki boyu üzerine $\mathrm{N}$ uygulamalarının \%1 düzeyinde önemli çıkması bitki boyunun farklı miktarlarda $\mathrm{N}$ uygulamasına bağlı olarak değiştiğini göstermektedir. 
Çizelge 4'den de görüldüğü gibi oluşturulan N bloklarındaki, en yüksek bitki boyu ortalaması $(56 \mathrm{~cm})$ bitkinin $\mathrm{N}$ ihtiyacından daha fazla $\mathrm{N}$ uygulanan $20 \mathrm{~kg} \mathrm{~N} \mathrm{da}^{-1}$ uygulamasından, en düşük bitki boyu ortalaması ise $(52 \mathrm{~cm})$ bitkinin $\mathrm{N}$ ihtiyacindan daha az $\mathrm{N}$ uygulanan $10 \mathrm{~kg} \mathrm{~N}$ da ${ }^{-1}$ uygulamasından elde edilmiştir.15 $\mathrm{kg} \mathrm{N} \mathrm{da}^{-}$ ${ }^{1}$ uygulamasından elde edilen bitki boy ortalaması $(53 \mathrm{~cm})$ ise diğer $\mathrm{N}$ uygulamaları arasında bir değerdir.

Uygulama parsellerine bakıldığında (Çizelge 4), parsellerdeki en yüksek bitki boyu $(58 \mathrm{~cm}) 20 \mathrm{~kg} \mathrm{~N} \mathrm{da}^{-1}$ bloğunda 4 kg BS da ${ }^{-1}$ uygulanan parselden elde edilmiştir. Burada uygulanan yüksek N dozu uygulaması ve KKBÇH'nın görülmemesi bitki boyunun yüksek olmasını sağlamıştır. En düşük bitki boyu (49 cm) $10 \mathrm{~kg} \mathrm{~N} \mathrm{da}^{-1}$ bloğunda BS uygulanmayan parselden elde edilmiştir. Bu parselde $\mathrm{KKBÇH}$ görüldüğünden ve uygulanan $\mathrm{N}$ dozu da bitki için yeterli olmadığından bitkinin vejetatif aksamı yeterince büyüyememiştir. Yapılan benzer çalışmalarda da (Fageria ve Baligar, 2005)belirtildiği gibi, N noksanlığı çeken bitkiler yavaş büyümekte ve yaprak alan indeksleri de azalmaktadır. $\mathrm{N}$ fazla verildiğinde ise bitkinin vejetatif aksamı hızlı ve normalden fazla büyümektedir. Yapılan araştırmalarda da (Stubbs et al., 1992; McMullen ve ark., 1997; Hekimhan ve ark., 2004; Hekimhan ve ark., 2005; Zhou ve ark., 2006; Anonim, 2016b) bildirildiği gibi, KKBÇH buğdayın gelişimini olumsuz yönde etkilemektedir.

\section{Uygulamaların m²'deki Başak Sayısına Etkileri}

Artan miktarlarda BS ve N uygulamalarının ekmeklik buğdayın $\mathrm{m}^{2}$ ' deki başak sayısına etkileri ile ilgili varyans analiz sonuçları Çizelge 2'de, $\mathrm{m}^{2}$ ' deki başak sayısına ilişkin ortalama değerler ve oluşan Duncan grupları ise Çizelge 4'de verilmiştir. Uygulamaların $\mathrm{m}^{2}$ 'deki başak sayısına etkileri istatistiksel bakımdan önemsiz çıkmıştır (Çizelge 2).

$\mathrm{m}^{2}$ ' deki en yüksek başak sayısı (660) $20 \mathrm{~kg} \mathrm{~N} \mathrm{da}^{-1} \mathrm{ve} 6 \mathrm{~kg} \mathrm{BS} \mathrm{da}^{-1}$ uygulanan parselden elde edilmiştir(Çizelge 4). Yüksek N dozu ve KKBÇH'nın bu parselde oluşmaması $\mathrm{m}^{2}$ ' deki başak sayısının yüksek olmasını sağlamıştır. $\mathrm{m}^{2}$ 'deki en düşük başak sayısı (492) ise $10 \mathrm{~kg} \mathrm{~N} \mathrm{da}^{-1}$ ve $\mathrm{BS}$ uygulanmayan parselden elde edilmiştir. Düşük $\mathrm{N}$ dozu ve KKBÇH'nın bu parselde oluşması $\mathrm{m}^{2}$ 'deki başak sayısını düşürmüştür. KKBÇH'nın durduğu 15 kg N da' 1 ve $20 \mathrm{~kg} \mathrm{~N} \mathrm{da}{ }^{-1}$ uygulamalarındaki $4 \mathrm{~kg} B \mathrm{Ba}^{-1}$ dozlarına kadar uygulanan BS dozları arttıkça KKBÇH'nınazaldığ (Finci, 1979; Stubbs et al., 1992; Hekimhan ve ark., 2005; Lougman ve ark., 2010) bildirdiği gibi, buğdayda $\mathrm{KKBÇH} \mathrm{bitkinin} \mathrm{verim} \mathrm{ve} \mathrm{verim} \mathrm{unsurlarını} \mathrm{olumsuz} \mathrm{yönde} \mathrm{etkilemektedir.}$

\section{Uygulamaların Başakta Tane Sayısına Etkileri}

Artan miktarlarda BS ve N uygulamalarının ekmeklik buğdayda başakta tane sayısına etkileri ile ilgili varyans analiz sonuçları Çizelge 2'de, başakta tane sayısına ilişkin ortalama değerler ve oluşan Duncan grupları ise Çizelge 4'de verilmiştir. Uygulamaların başakta tane sayısına etkileri istatistiksel bakımdan önemsiz çıkmıştır (Çizelge 2).

Uygulama parsellerine bakıldığında (Çizelge 4)başakta en yükssek tane sayısı (28) $15 \mathrm{~kg} \mathrm{~N} \mathrm{da}^{-1}$ ve $4 \mathrm{~kg} \mathrm{BS} \mathrm{da}^{-}$ ${ }^{1}$ uygulamasından alınmıştır. Bu parselde, optimum $\mathrm{N}$ dozu uygulanması ve KKBÇH'nın oluşmaması başakta en yüksek tane sayısı değerinin alınmasını sağlamıştır. Başakta en düşük tane sayısı (21) $15 \mathrm{~kg} \mathrm{~N}$ da $^{-1}$ ve BS uygulanmayan yerden alınmıştır. Bu parselde, KKBÇH'nın bitki gelişimine olumsuz etki ettiğinden başakta en düşük tane sayısı alınmıştır. Aynı şekilde bazı araştırıcılar da (McMullen ve ark., 1997; Hekimhan ve ark., 2004; Hekimhan ve ark., 2005; Zhou ve ark., 2006) KKBÇH'nın buğdayda verim ve verim unsurlarını olumsuz etkilediğini bildirmişlerdir.

\section{Uygulamaların Bin Tane A ğırlığına Etkileri}

Artan miktarlarda BS ve N uygulamalarının ekmeklik buğdayda bin tane ağırlığına etkileri ile ilgili varyans analiz sonuçları Çizelge 2'de, bin tane ağırlığına ilişkin ortalama değerler ve oluşan Duncan grupları ise Çizelge 4'de verilmiştir. Buğdayda bin tane ağırlığına sadece N uygulamasının etkisi \%5 düzeyinde önemli çıkmıştır (Çizelge 2). Bin tane ağırlığı üzerine N uygulamalarının \%5 düzeyinde önemli çıkması bin tane ağırlığının farklı miktarlarda N uygulamasına bağlı olarak değiștiğini göstermektedir.

Çizelge 4'den de görüldüğü gibi, oluşturulan N bloklarındaki en düşük bin tane ağırlığı ortalaması (39,2 g) bitkinin $\mathrm{N}$ ihtiyacından daha azN uygulanan $10 \mathrm{~kg} \mathrm{~N} \mathrm{da}^{-1}$ uygulamasından, en yüksek bin tane ağırlığı ortalaması $(43,5 \mathrm{~g})$ optimum $\mathrm{N}$ uygulanan $15 \mathrm{~kg} \mathrm{~N} \mathrm{da}^{-1}$ uygulamasından alınmıştır, bitkinin ihtiyacından daha fazlaN uygulanan $20 \mathrm{~kg} \mathrm{~N} \mathrm{da}^{-1}$ uygulamasından ölçülen bin tane ağırlığı (42 g) değeri optimum N uygulanan $15 \mathrm{~kg} \mathrm{~N} \mathrm{da}^{-}$ ${ }^{1}$ uygulamasından elde edilen bin tane ağırlı̆̆ değerinden az ölçülmüştür. Bazı araştırmacıların da bildirdiği gibi 

(Lopez-Bellido ve ark., 2000; Kacar ve Katkat, 2007) fazla azot dozu bazı verim unsurları ve bin tane ağırlığının azalmasına sebep olmaktadır. Bu durum dengesiz beslenmeden kaynaklanabilir.

Uygulama parsellerine bakıldığında (Çizelge 4), parsellerdeki en yüksek bin tane ağırlığ (45 g) $15 \mathrm{~kg} \mathrm{~N} \mathrm{da}^{-1}$

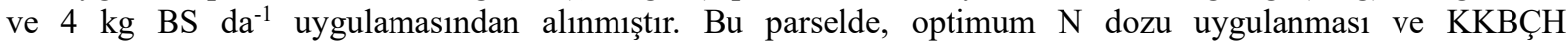
görülmediğinden en yüksek bin tane ağırlığı değerinin alınmasını sağlamıştır. En düşük bin tane ağırlığı (36.25 g) ise $10 \mathrm{~kg} \mathrm{~N} \mathrm{da}{ }^{-1}$ ve BS uygulanmayan parselden alınmıştır. Bu parselde, uygulanan $\mathrm{N}$ dozu düşük olduğundan ve KKBÇH görüldüğünden en düşük bin dane ağırlığı değeri elde edilmiştir.

\section{Uygulamaların Hasat İndeksine Etkileri}

Artan miktarlarda BS ve N uygulamalarının ekmeklik buğdayda hasat indeksine etkileri ile ilgili varyans analiz sonuçları Çizelge 2'de, hasat indeksine ilişkin ortalama değerler ve oluşan Duncan grupları ise Çizelge 4'de verilmiştir.

Buğdayda hasat indeksine sadece $\mathrm{N}$ uygulamasının etkisi \%5 düzeyinde önemli çıkmıştır (Çizelge 2). Hasat indeksi üzerine $\mathrm{N}$ uygulamalarının $\% 5$ düzeyinde önemli çıkması hasat indeksinin farklı miktarlarda $\mathrm{N}$ uygulamasına bağlı olarak değiştiğini göstermektedir.

Azot bloklarının ortalaması olarak bakıldığında(Çizelge 4), en yüksek hasat indeksi ortalaması (\%48) $10 \mathrm{~kg} \mathrm{~N}$ $\mathrm{da}^{-1}$ uygulamasından, en düşükhasat indeksi ortalaması (\%43) ise $20 \mathrm{~kg} \mathrm{~N} \mathrm{da}{ }^{-1}$ uygulamasından alınmıştır, $15 \mathrm{~kg} \mathrm{~N}$ $\mathrm{da}^{-1}$ uygulamasından ise ölçülen hasat indeksi değeri (\%44) diğer iki uygulama arasında bir değerdir.

Uygulama parsellerine bakıldığında (Çizelge 4), en yüksek hasat indeksi (\%50) $10 \mathrm{~kg} \mathrm{~N} \mathrm{da}^{-1} \mathrm{ve}^{4} \mathrm{~kg} \mathrm{BS} \mathrm{da}^{-1}$ uygulamasından alınmıştır.Bu parselde, düşük $\mathrm{N}$ dozu uygulanmasından dolayı bitkinin vejetatif aksamı yeterince gelişemediğinden hasat indeksi değeri yüksek çıkmıştır. En düşük hasat indeksi değeri (\%39) ise $20 \mathrm{~kg} \mathrm{~N} \mathrm{da}^{-1} \mathrm{ve}$ $0.5 \mathrm{~kg}$ BS da ${ }^{-1}$ uygulamasından alınmıştır. Bu parselde uygulanan $\mathrm{N}$ dozu yüksek olduğundan bitkinin vejetatif aksamı daha fazla gelişme göstermiş ve hasat indeksi değeri düşük çıkmıştır. Birçok araştırmacının da (Gezgin, 2003; Kacar ve Katkat 2007) bildirdiği gibi, genellikle ekmeklik buğdaylara $12-14 \mathrm{~kg} \mathrm{~N} \mathrm{da}^{-1}$ uygulaması önerilmektedir. Buğdayda N noksanlığı sap ve tane veriminin azalmasına sebep olduğu gibi fazlası da büyümeyi, yani sap gelişmesini artırarak tane oluşumu ile verimin önemli düzeyde azalmasına sebep olmaktadır.

\section{Uygulamaların Tanenin Protein Oranlarına Etkileri}

Artan miktarlarda BS ve N uygulamalarının ekmeklik buğday tanesinde protein oranına etkileri ile ilgili varyans analiz sonuçları Çizelge 2'de, tanede protein oranına ilişkin ortalama değerler ve oluşan Duncan grupları ise Çizelge 4'de verilmiştir.

Varyans analizi sonuçlarına göre (Çizelge 2) BS ve N uygulamalarının tanede protein oranı üzerine istatistiki bakımdan \%1 düzeyinde önemli bulunmuştur. Tanede protein oranı üzerine BS ve N uygulamalarının istatistiki olarak önemli çıkması tanede protein oranının artan miktarlarda BS ve N uygulamalarına bağlı olarak değiştiğini göstermektedir. En yüksek protein oranı (\%12.88) bitkinin toprak analizi sonuçlarına göre ihtiyaç duyduğu miktarda, $15 \mathrm{~kg} \mathrm{~N} \mathrm{da}^{-1}$ dozu ile birlikte $4 \mathrm{~kg} \mathrm{da}^{-1}$ BS uygulanan parselden alınmıştır (Çizelge 4). Bu parselde, optimum N dozu uygulandığından ve KKBÇH görülmediğinden en yüksek protein oranı elde edilmiştir. En düşük protein oranı ise (\% 7.35) bitkinin $\mathrm{N}$ ihtiyacından daha az $\mathrm{N}$ uygulanan $10 \mathrm{~kg} \mathrm{~N} \mathrm{da}^{-1} \mathrm{ve}$ BS uygulanmayan parselden elde edilmiştir. Bu parselde, bitkinin ihtiyacı olan $\mathrm{N}$ dozundan daha az $\mathrm{N}$ uygulaması yapıldığından bitkinin $\mathrm{N}$ ihtiyacı karşılanamamış ve bu parselde KKBÇH'da görüldüğünden tanede düşük protein oranı elde edilmiştir.

Azot bloklarındaki protein ortalamalarına bakıldığında (Çizelge 4), en düşük protein ortalaması (\%8.48) $10 \mathrm{~kg}$ $\mathrm{N} \mathrm{da}^{-1}$ uygulamasından alınmıştır. Bu $\mathrm{N}$ dozu bitkinin $\mathrm{N}$ ihtiyacını karşılayamadığından en düşük protein oranı ortalaması oluşmuştur. En yüksek protein ortalaması (\%11.00) ise $15 \mathrm{~kg} \mathrm{~N} \mathrm{da}^{-1}$ uygulamasından alınmıştır. $15 \mathrm{~kg}$ $\mathrm{N} \mathrm{da}^{-1}$ uygulaması bitkinin $\mathrm{N}$ ihtiyacını karşılamıştır. $20 \mathrm{~kg} \mathrm{~N} \mathrm{da}^{-1}$ uygulamasından alınan protein ortalaması da (\%10.53) $15 \mathrm{~kg} \mathrm{~N} \mathrm{da}^{-1}$ uygulamasına göre düşük ölçülmüştür. Birçok araştırmacı da (Tipples ve ark., 1976; Kacar ve Katkat 2007) artan dozlarda N uygulamasının tanede protein oranını artırdığını, ancak fazla N uygulandığında ise verim ve verim unsurları değerlerinde gerileme meydana geldiğini bildirmişlerdir. Diğer bir araştırmada da buğdayda KKBÇH'nın bitkinin verim unsurları arasında, bin dane ağırlığını olumsuz yönde etkilediği bildirilmiştir (Finci 1979;Stubbs et al., 1992; Wallwork, 2000; Hekimhan ve ark., 2005, Lougman ve ark., 2010).Bu araştırmaya benzer yapılan bir araştırmada da Fusariumgraminearum 'u kapsayan Fusarium türlerinin tahıllarda neden olduğu başak yanıklığı hastalığı nemli ve yarı nemli iklimlerde ürünlerin kalitesini bozarak verimi düşürdüğü bildirilmiştir (McMullen ve ark., 1997; Hekimhan ve ark., 2004; Zhou ve ark., 2006). 
Sonuç

Sonuç olarak; Araştırmada uygulanan $10 \mathrm{~kg} \mathrm{~N} \mathrm{da}^{-1}$ dozu bitkinin $\mathrm{N}$ ihtiyacını karşılayamamış, verim ve verim unsurları istenen düzeyde sonuçlar vermemiştir. $20 \mathrm{~kg} \mathrm{~N} \mathrm{da}^{-1}$ uygulama dozunun ise bitkinin ihtiyaç duyduğu $\mathrm{N}$ miktarından fazla olduğu anlaşılmış ve bu uygulamadan da istenen verim ve verim unsurları değerleri alınamamıştır. En yüksek verim ve verim unsurları değerleri $15 \mathrm{~kg} \mathrm{~N} \mathrm{da}^{-1}$ uygulamasından alınmıştır.

Uygulanan $\mathrm{N}$ dozu arttıkça KKBÇH'nın skala değerinde artış meydana gelmiş, yani bitkilerde görülen $\mathrm{KKBÇH} \mathrm{düzeyi} \mathrm{artmıştır.}$

Buğday üreticilerimizin ürünlerinde ekonomik zarar meydana getiren KKBÇH ile mücadelede, BS uygulamalarının sonuçlarının $\mathrm{N}$ uygulamalarıyla birlikte araştırıldığı çalışmamızda KKBÇH $10 \mathrm{~kg} \mathrm{~N} \mathrm{da}^{-1}$

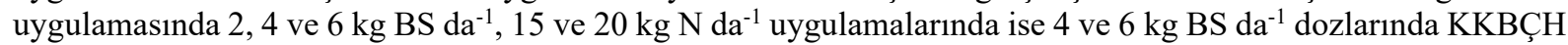
görülmemiştir. Buradan da buğday bitkisinde $4 \mathrm{~kg} \mathrm{BS} \mathrm{da}^{-1}$ uygulama dozunda KKBÇH'nın görülmediği anlaşılmıştır.

KKBÇH $10 \mathrm{~kg} \mathrm{~N} \mathrm{da}{ }^{-1}$ uygulamasında $2 \mathrm{~kg} \mathrm{BS} \mathrm{da}^{-1}, 15$ ve $20 \mathrm{~kg} \mathrm{~N} \mathrm{da}{ }^{-1}$ uygulamalarında ise $4 \mathrm{~kg}^{\mathrm{BS}} \mathrm{da}^{-1}$ dozlarına kadar uygulanan BS dozları arttıkça azalmıştır. Kardeşlenme ile sapa kalkma dönemi arasında $4 \mathrm{~kg}$ BS $\mathrm{da}^{-1}$ dozunun yeterli su ile KKBÇH ile mücadelede pülverizasyonda kullanılabileceği anlaşılmıştır. $4 \mathrm{~kg}$ BS da ${ }^{-1}$ uygulamasıyla kontrole göre KKBÇH \%100 oranında azaldığı, dolayısıyla hastalığın oluşmadığı belirlenmiştir.

Buğday çeşidi ve toprak özelliklerine göre farklılık göstermekle birlikte Sarayönü İlçesi sulu koşullarında ekmeklik buğdayda yüksek verim ve verim unsurları elde edebilmek için $15 \mathrm{~kg} \mathrm{~N} \mathrm{da}^{-1}$ dozu önerilebilir. Daha kesin öneriler için farklı tarla ve ekmeklik/makarnalık buğday çeşitlerinde farklı $\mathrm{N}$ doz ve formlarına ilişkin tarla denemeleri sürdürülmelidir.

Ekmeklik buğday üreten üreticilerimize $\mathrm{KKBÇH} \mathrm{ile} \mathrm{mücadele} \mathrm{için} \mathrm{kardeşlenme} \mathrm{ile} \mathrm{sapa} \mathrm{kalkma} \mathrm{dönemi}$ arasında $4 \mathrm{~kg} \mathrm{BS} \mathrm{da}^{-1}$ dozunun yeterli çözelti halinde buğday bitkilerine pülverizasyonu tavsiye edilebilir. 


\section{Kaynakça/References}

Aktaş H., Kınacı E., Yıldırım, A. F., Sayın L. ve Kural, A., 1999. Konya yöresinde hububatta sorun olan kök ve kök boğazı çürüklüğü etmenlerinin hububatta verim komponetlerine etkileri ve mücadelesi üzerinde araştırmalar. Orta Anadolu Hububat Tarımının Sorunları ve Çözüm Yolları Semp., 8-11 Haziran 1999, Konya, sf: 392-403.

Anonim, 2016a. http://www.tuik.gov.tr/UstMenu.do?metod=temelist (Bakma tarihi 05.09.2016)

Anonim, 2016b. Serin İklim Tahıllarında Kök ve Kök Boğazı Hastalıklarının Dünü, Bugünü ve Mücadelesi. Zirai Mücadele Merkez Araşt. Enst. Md.lüğü, Ankara.

Bayraklı, F., 1987. Toprak ve Bitki Analizleri. O.M. U. Ziraat Fak. Yay., No: 17, Samsun.

Cook R.J., 1992. Wheatroothealtmanagamentandenvironmentalconcern. Can. J. PlantPathology, 14: 76-85.

Çölkesen, M., Eren, N., Ökten, A. ve Akıncı, C., 1993. Şanlıurfa'da Kuru ve Sulu Koşullarda Uygun Makarnalık Buğday Çeşitlerinin Belirlenmesi Üzerine Bir Araştırma. Makarnalık Buğday ve Mamulleri Semp. Sf: 533-539, Ankara.

Duffy, B.K. andDefag, G., 1999. Macro and Micro Element fertilizersinfluencetheseverity of fusariumcrownandroot rot of tomato in a soillessproductionsystem. Hortscience 34(2): 287-291.

Ellmer, F., Erekul, O. andKöhn, W., 2001. EinflusslangjährigdifferenzierterorganischmineralischerDüngungauf den Ertrag, dieErtragsstrukturunddieBackqualitätvonWinterweizen. Archives of AgronomyandSoilSci., 47: 423-444.

Fageria, N. K. andBaligar, V. C., 2005. Enhancingnitrogenuseefficiency in cropplants. Adv. Agron., 88: 97-185.

FAO, 1990. Micronutrients Assessment at the Country Level. p. 1-208. An International Study (M. Sillanpä, ed.), FAO Soil Bulletin 63. Published by FAO, Roma, Italy.

Finci S., 1979. Buğdayın kök ve kök boğazı hastalıkları ve korunma çareleri. Gıda-Tarım ve Hayvancılık Bakanlığı Zirai Mücadele ve Zirai Karantina Genel Müdürlüğü, Çiftçi Broşürü No: 21, 15 s.

Follett, R.H., Lindsay, W.L., 1970. Profile Distribution of Zinc,Iron, Manganese, and Copper in Calorodo Soils. CalorodoExp. Sta. Tech. Walsh and Bealon, Soil Sci Soc. ofAm. Inc. Medison, Winconsin, USA.

Genç, İ., 1974. Yerli ve Yabancı Makarnalık ve Ekmeklik Buğday Çeşitlerinde Verim ve Verime Etkili Başlıca Karakterler Üzerinde Araştırmalar. Ç.Ü. Ziraat Fak. Yay. No: 82, Adana.

Gezgin, S., 2003. Buğdayın Gübrelenmesi. Ticaret Borsası Derg., 6(14): 23-27, Konya.

Gökmen, F., Zengin, M., Arısoy, R.Z., Taner, S., Gezgin, S. ve Çakmak, İ., 2008. Amonyum Nitrat ve Entec Gübrelerinin Çinkosuz ve Çinkolu Bloklarda Yetiştirilen Makarnalık Buğdayın Verim ve Verim Unsurlarına Etkileri. Ülkesel Tahıl Semp., 2-5 Haziran 2008, Konya. Sf: 536-551.

Hekimhan, H., Bagcı, A., Nicol, J., Arısoy, T. and Sahin, S., 2004. Drylandroot rot: a majorthreattowintercerealproductionundersub-optimal growingconditions. 4th Intl. Crop. Sci. Congress, 26-1 Oct. Brisbane, Australia.

Hekimhan H., Bağcı S.A., Nicol J., Tunalı, B., 2005. Kök ve kök boğazı çürüklüğü hastalığı etmenlerinin bazı kışlık hububat verimleri üzerine etkileri. Türkiye VI. Tarla Bitkileri Kongresi Bildirileri, 5-9 Eylül 2005, Antalya, Cilt 1: 201-206

Hoffland, E., Dicke, M., Tintelen, W,V., Dickman, H., andBeusichem M.L., 2000. Nitrogenavailabilityanddefence of tomatoagainsttwospottedspired mite. Journal of ChemicalEcology, 26: 2697-2711.

Jokinen, R., 1981. TheMagnesiumStatus of Finnish Mineral SoilsandtheRequirement of theMagnesiumSupply. Magnesium-Bull. 3, H. 1a: 1-

Kacar, B. ve Katkat, A. V., 2007. Gübreler ve Gübreleme Tekniği. Genişletilmiş ve Güncellenmiş 2. Baskı. Nobel Yay. No: 1119, ISBN 9789944-77-159-7, Ankara.

Koca Y.. 1999. Yüzyılın Jeoekonomik gücü tahılın üretimi, ticareti ve uluslararası ilișkilere etkileri. Orta Anadolu'da Hububat Tarımının Sorunları ve Çözüm Yolları Semp.., 8-11 Haziran 1999, Bahri Dağdaş Milletlerarası Kışlık Hububat Araşt. Merkezi Md.lüğü, Konya, Sf: 539-546.

Lawrence, E., D., Elmer, W.H. and Don, M.H., 2007. Mineral Nutrition and Plant Disease. APS Press, St. Paul, MN. 278 p.

Lindsay, W. L. andNorvell, W. A., 1978. Development of DTPA Soil Test forZinc, Iron, ManganeseandCopper. SoilSci. Soc. of Amer. J., 42: 421-428.

Lopez-Bellido, L., Lopez-Bellido, J. R., Castillo, J. E. and Lopez-Bellido, F. J., 2000. Effects of tillage, croprotationandnitrogenfertilization on wheat-grainqualitygrownunderrainfedMediterraneanconditions. Agron. J., 92: 1054-1063.

Loughman R., Loughman G., MacNish and McLeod W., 2010. Wheat book. Revised by: R. Loughman, D. Wright, W. MacLeod, J. Bhathal, D. Thackray. Chapter 10: 203-216. 
McMullen, M.P., Jones, R. and Gallenbery, D.. 1997. Scab of wheat and barley : are emerging disease of devastating impact. Plant Dis. 81:1340-1348.

Nicol J.M., Bagcı A., Bolat N., Erginbas G., Sahin E., Yıldırım A.F., Ozdemir F., Yorgancılar A. veKılınç A. 2008. Identification of bread wheat resistance against dryland crown rot (Fusarnumculmorum) under inoculated field and controlled greenhouse conditions in Turkey. Trethowan, R.T., Manes, Y. 10th International Fusarium Workshop, 30th August-2nd September 2008/Italy, Abstract published in International Journal plant Pathology 2008: 90(3)

Reis, E.M., Cook, R.J. andMcNeal, B.L., 1982. Effect of mineral nutrient on take-all of wheat. Phytopathol., 72:224-229.

Richard, L.A., 1954. DiagnosisandImprovement of Salineand Alkaline Soils. Handbook 60, U.S. Dept. ofAgriculture.

Sağlam, N., 1999. Yabancı kökenli beş ekmeklik buğday çeşidinde uygulanan farklı azot dozlarının verim ve verim unsurlarına etkisi ile ekonomik azot dozunun belirlenmesi. Türkiye 3. Tarla Bitkileri Kongresi, Sf. 372-376, Adana.

Stubbs, R.W., Prescott, J.M., Saari, E.E. andDubin, H.J., 1992. Tahıl Hastalıkları MetodlarıKlavuzu. S. 120.

Tipples, K. H., Dubetz, S. and Irvine, G. N., 1976. Effects of high rates of nitrogen on Neepawa wheat grown under irrigation. II. Milling and baking quality. Can. J. Plant Sci., 57: 337-350.

Tosun, O. ve Yurtman, N., 1973. Ekmeklik Buğdaylarda (Triticumaestivum L. Em Thell) Verime Etkili Morfolojik ve Fizyolojik Karakterler Arasındaki İlişkiler. A.Ü. Ziraat Fak. Yıllığı, 23: 418-431, Ankara.

Ülgen, N., Yurtsever, N., 1974. Türkiye Gübre ve Gübreleme Rehberi. Toprak ve Gübre Araşt. Enst. Teknik Yayın No: 28, Ankara.

Wallwork, H., 2000. Cereal root and crown diseases. SARDİ, Adelaide, 58 p.

Wiese M.V., 1991. Compendium of Wheat Diseases. St. Paul, Minnesota, USA. American Phytopathology, 112 p.

Wolf, B., 1971. The Determination of Boron in Soil Experiment on The Application of Slow-Release Boron Extracts, Plant Materials, Composts, Manures, Water Fertilizer: Part II: Behavior of Boron in The Soil. In: and Nutrient Solutions. Soil Sci. Plant Anal., 2: 363.

Yurtsever, N., 1984. Deneysel İstatistik Metotlar. (Mülga) Köy Hizmetleri Genel Md.lüğü Toprak ve Gübre Araşt. Enst. Md.lüğü Yay. No: 121, Teknik Yay. No: 56, Ankara.

Yürür, N., Tosun, O., Eser, D. ve Geçit, H.H., 1981. Buğdayda Ana Sap Verimi ile Bazı Karakterler Arasındaki İlişkiler. A.Ü. Ziraat Fak. Yay. No: 775 , Ankara.

Zhou, W.C., Eudes, F. and Laroche, A., 2006. Identification of differentially regulated proteins in response to a compatible interaction between the pathogen Fusarium graminearum and its host in T. aestivum. Proteomics, 6: 4599-4609. 